\title{
Koloratzaile-laserra, ezinbesteko argi iturria eguneroko bizitzan
}

\author{
(Dye lasers, essential light source for daily life)
}

\author{
Edurne Avellanal-Zaballa, Jorge Bañuelos ${ }^{1}$ \\ ${ }^{1}$ Kimika Fisiko Saila, Zientzia eta Teknologia Fakultatea (UPV/EHU), \\ 644 PK, 48080 Bilbao \\ jorge.banuelos@ehu.es
}

DOI: $10.1387 /$ ekaia.19591

Laburpena: Gure eguneroko bizitzan erabiltzen ditugun hainbat gailu elektroniko laser-igorpenean oinarritzen dira. Erradiazio mota honen ezaugarri bereziak, hots, monokromatizitatea, koherentzia eta norabide zuzena, aplikazio arrakastatsu eta eraginkorraren arrazoi nagusia dira. Lan honetan, gure helburu nagusia izan da laserren garrantzia agerian jartzea eta azaltzea zergatik agertzen den erradiazio mota hori. Horretarako, laserren oinarria azaldu da eta argiaren igorpen-mota hori lortzeko beharrezkoak diren eskakizunak aipatu dira. Bukaeran, laser organiko izeneko gailuetan ipini dugu arreta; horietan, koloratzaile fluoreszenteak erabiltzen dira ingurune aktibo gisa. Ildo honetatik, gure ikerkuntza-taldean azken urteetan orokorrean egindako aurrerapausoak iruzkintzen dira. Egindako ikerkuntzaren helburua, laser-seinalearen eraginkortasuna eta ponpaketaren aurrean egonkortasuna areagotzeaz gain, espektro-eremu ultramore ikusgai osoan zehar koloratzaile-laserrak egoera likidoan zein solidoan lortzea izan da.

Hitz gakoak: laserra, koloratzaileak, fluoreszentzia.

Abstract: Many of the electronic devices, which we manage usually in our daily life, are based on the laser emission. The key signatures of this kind of radiation, such as, monochromaticity, coherency and directionability, enable to apply then successfully and efficiently. In the herein reported work, the main goal has been to show the viability and key role of lasers, as well as to unravel the underlying processes to achieve this kind of radiation. Thus, we explain the fundamental basis of lasers and the guidelines and requirements, which rules the display of this sort of light emission. Finally, we have focused on organic lasers, where fluorescent dyes are placed in the active medium. In this regard, we highlight the main advances carried out during the last years in our research group. The main aim of such research activity has been not only to improve the efficiency and tolerance to a strong pumping regime of the laser signal, but also to develop dye lasers in liquid and solid state across the whole ultraviolet-visible spectral region.

Keywords: laser, dyes, fluorescence. 


\section{SARRERA}

Laserra (Light Amplification by Stimulated Emission of Radiation) erradiazio elektromagnetikoak suspertutako igorpenean oinarritzen den anplifikazio optiko prozesuari esker argia igortzen duen tresna da. 1960. urtean lortu zen lehen aldiz suspertutako igorpenaren bitartez argi ikusgaia anplifikatzea. Urte bat baino ez pasatu ostean, erretinako ehunak gatzatzeko laserra erabili zen. 1964an, laserra odontologian erabiltzen hasi zen, eta 1969an, Xerox enpresak kolorezko lehen laser-inprimagailua sortu zuen. 1971n, bestalde, General Motors enpresan, helio-neon laserrean oinarritutako lehen barra-koderako eskanerra ezarri zen. Teknologiaren industrian ez ezik ikerkuntza zientifikoan eta gure eguneroko bizitzan ere izan duen izugarrizko eragina dela eta, historia berriko aurkikuntzarik garrantzitsuenetarikotzat hartzen da laserra [1].

Garrantzi handia izan du laserrak ikerkuntza zientifikoan. Izan ere, lehen aldiz sortu zenetik (1960) gaur egun arte (2018) hamar Nobel sari lotuta daude, era batean edo bestean, laserrarekin [2]. Lehenengoa 1964. urtean izan zen: Townes, Basov eta Prokhorov-ek Fisika Nobel saria irabazi zuten, maserrari buruz egin zuten ikerketan oinarrituta anplifikadoreak eta osziladoreak sortzeagatik. Azken gertaera hau ezinbestekoa izan zen laserraren oinarria aurrera eramateko [3]. Honen ostean, beste hainbat sari lortu ziren: esaterako, 1971n, 1981ean edo 1997an; azkena orain dela lau urte izan zen, 2014an. Urte hartako Kimika Nobel saria bioirudi-detekzioaren hobekuntzarekin lotuta dago, ordura arte mikroskopia fluoreszentearen bereizmen espaziala difrakzio-mugaren $(\lambda / 2)$ menpe baitzegoen. Horregatik, $\mathrm{S}$. Hell irakasleak kitzikapen laser bi erabiliz, STED mikroskopia (Stimulated Emission Deplection) garatu zuen [4] eta, aldi berean, E. Betzig eta W. Moerner irakasleek, zona berean laser erradiazioarekin ondoz ondoko miaketa gauzatuz, molekula bakar baten mikroskopia garatu zuten [5, 6]. Izan ere, ikerkuntza arloan laserrei esker bereizmen handiko hainbat teknika espektroskopiko berri garatu dira maila molekularrean informazioa eskuratzeko (eskala nanometrikoan: $10^{-9} \mathrm{~m}$ ) eta prozesuak ultraazkarrak egoera kitzikatuan jarraitzeko (fentosegundo-eskalan $\left(10^{-15} \mathrm{~s}\right)$, edo attosegundo-eskalan $\left(10^{-18} \mathrm{~s}\right)$ laser-pultsu oso laburrak erabiliz).

Ikerketan egin diren aurrerapausoei esker, laserra hainbat aplikaziotan erabili ohi da,eta gure eguneroko bizitzan ezinbestekoa den tresna bilakatu da. Haren garapenaren inguruan egin diren aurrerapenak gero eta harrigarriagoak dira. Bereziki, laserrak berehala hasi ziren gure bizitzako eguneroko eremurik sinpleenetan parte hartzen: hainbat zeregin erraztuz [7]. Esate baterako, inprimagailuak edo etxeko gailu elektroniko asko (disko optikoen irakurgailu eta grabagailuak) laserretan oinarritzen dira. Beste adibide adierazgarri bat barra-kodeen irakurgailua da. Gaur egun industria horrek urtero milaka milioi euro mugitzen ditu [8], eta horiez da harritze- 
koa gaur egun barra-kodea daramaten artikuluen kopurua kontuan hartzen badugu: jakiak, liburuak, aldizkariak; eta ospitaleetan ere erabiltzen da: barra-kodea duen eskumuturreko baten bitartez identifikatzen dira gaixoak. Mota honetako irakurgailuen funtzionamendua hurrengoa da: laserra barra-kodearen gainean kokatzen da, marra zuri eta beltzez osatuta dagoena. Marra beltzek laserraren erradiazioa absorbatzen dute eta marra zuriek, berriz, islatzen dute. Horrela, zonalde zuria edo beltz baten gainean kokatuz gero, islatutako seinalearen intentsitatea altuagoa edo baxuagoa izango da. Irakurgailura itzultzen den argia fotodetektore batera bidaltzen da, zeinak argi-intentsitatea pultsu elektriko bihurtzen duen. Ekorketa aurrera eramateko, lehenik kode osoa irakurtzeko biraka dabilen ispilu batera eramaten da laserraren argia; hain abiadura handian, ezen gizakiaren begiak puntuak ikusi ordez marra bakar bat ikusten baitu. laserraren argia kode osoa irakurtzeko biraka dabilen ispilu batera eramaten da, hain altua den abiadura batean, ezen gizakiaren begiak puntuak ikusi ordez marra bakar bat ikusten baitu. Hau da, argi-seinale bat dena, seinale elektroniko bihurtzen dute, eta ordenagailu baten bitartez produktuari buruzko informazio guztia zenbaki edo/eta hizki bihurtzen da. Modu honetan, egin beharreko lan guztia errazten da denbora aurreztuz.

Ohiko argia arruntarekin alderatuta laserrak aurkezten dituen ezaugarri paregabeetan oinarritzen da haren arrakasta (1. irudia). Izan ere, erradiazio monokromatiko eta koherente mota honi esker argia puntu txiki batean kontzentratu daiteke eta energia izugarri altuak lor daitezke, nahiz eta argiak distantzia oso luzeetara bidaiatu.

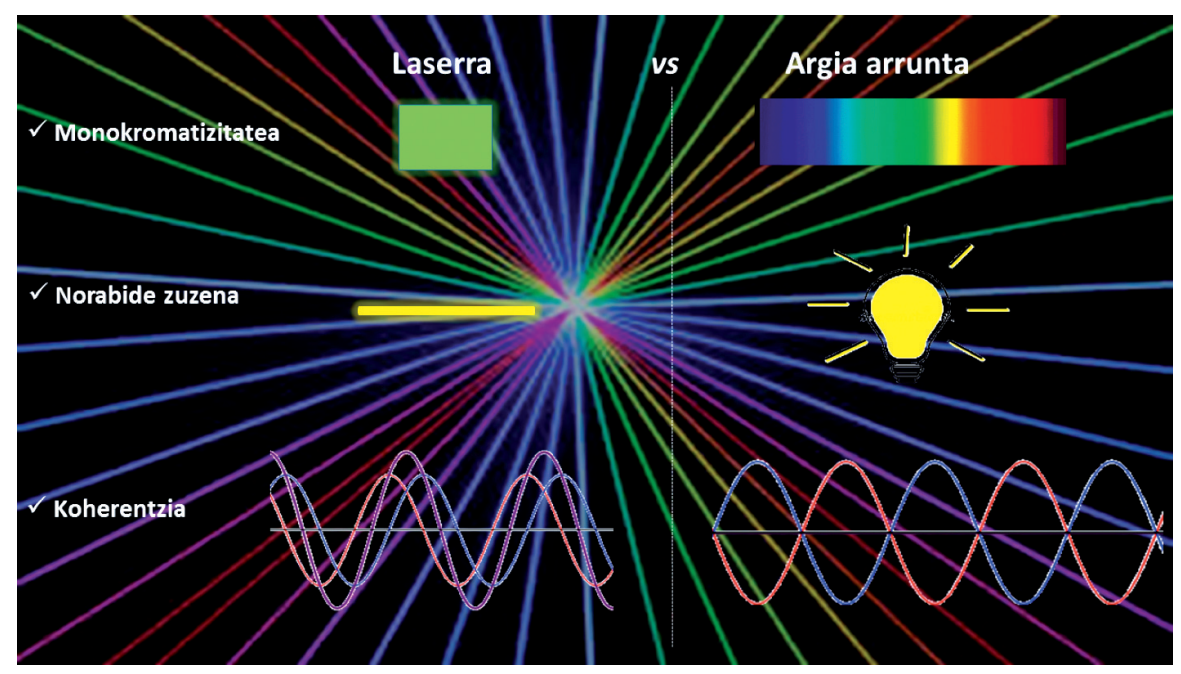

1. irudia. Laserren propietate nagusiak ohiko argiarekin alderatuta. 
Ondorioz, laserrak gogotik erabiltzen ditugu, ez gure eguneroko bizitza erosoago egiten dutelako soilik, baizik eta beste hainbat arlotan milaka aplikazio dituztelako $[9,10]$. Industrian, haien potentzia aprobetxatuz, materialak prozesatzeko erabiltzen dira laserrak: materialak mozteko, soldatzeko, modelatzeko, lurruneztatzeko eta desegiteko, besteak beste. Metrologian ere erabiltzen da, zehaztasun handiko neurketak egiteko, laserraren norabidea zuzena baita. Kanpoko espazioko komunikazioetarako, egokia da laserra: distantzia oso luzeak eta intentsitate galdu barik argia garraiatzeko, eta baita telefono eta konputagailuen zuntza optikoak garatzeko, edota holografian 3D irudiak berregiteko ere. Medikuntzan, ebakuntzetan sarritan erabiltzen dira laserrak, inguruneko ehunak kaltetu gabe ebaki garbiak egiteko (esate baterako, kornearen kirurgian), eta, kirurgia plastikoan, oro har orokorrean larruazaleko gaixotasunak sendatzeko. Halaber, ikerkuntza zientifikoan ezinbestekoa da laserren erabilera. Haren bidez, goi-mailako teknika espektroskopikoak eta mikroskopikoak garatu ez ezik, goian aipatu den bezala, atmosferan dauden kutsatzaileak edo lurraren lurrazaleko mugimenduak ere detektatzen dira. Partikulak azeleratzea eta erreakzio kimikoak selektiboki sorraraztea dira haren beste aplikazio batzuk.

Ikusten denez, laserra historian zehar hainbat aplikaziotarako baliagarria izan da eta haren garrantzia ukaezina da. Baina, zerk egiten du laserra hain baliozko tresna izatea? Zer da laserra? Nola funtzionatzen du? Hurrengo lerroetan, erantzuna emango zaie galdera horiei, eta koloratzailelaserren kasu berezia eta horien erabilera anizkoitza ere deskribatuko da.

\section{LASERRAREN FUNTZIONAMENDUA}

Esan bezala, laserra erradiazio elektromagnetikoaren sorta baten intentsitatea anplifikatzen duen gailua da; beste era batean esanda: argiaren intentsitatea handitzen du, atomoek eta molekulek suspertutako erradiazioa igorri ahal izateko duten abantaila aprobetxatuz. Ondorioz, haren barruan ingurunea zeharkatzen duen erradiazioa areagotzen da. Erradiazioa anplifikatzeaz gain, erradiazio horrek koherentzia, monokromatizitate eta norabide zuzeneko propietateak aurkezten ditu (1. irudia). Baina hau guztia ulertu ahal izateko, aurretik oinarrizko kontzeptu batzuk azaldu behar ditugu.

\subsection{Argiaren absortzioa eta igorpena}

Ezaguna den bezala, atomoetan elektroiak euren inguruan biraka dabiltza orbitak eratuz. Atomo horiek egonkorrak dira, mugimenduan zehar orbita bakoitzean dagoen elektroiak energia konstante mantentzen du eta. Orbitaren inguruko aldaketa bakoitzak elektroiaren energiaren aldaketa bat eragiten du; prozesu horri energia mailen arteko trantsizio elektroniko deritzo. Baina, Fi- 
Koloratzaile-laserra, ezinbesteko argi iturria eguneroko bizitzan

sika Kuantikoaren arabera, atomo baten elektroiek ezin dute edozein orbita bete. Horren ondorioz, ezin dira edozein energia mailatan egon [11]. Elektroia energia maila baxuenean dagoenean oinarrizko egoeran $\left(\mathrm{S}_{0}\right)$ dagoela diote, eta energia maila gorenean, ordea, egoera kitzikatuan $\left(S_{1}\right)$.

Argia (ultramorea, ikusgaia edo infragorri hurbila) atomoaren energia mailen arteko trantsizio elektronikoak bultzatzeko gai da, absortzio- eta igorpen-prozesuen bitartez. Era berean, argia partikulez (fotoiez) osatuta dago eta horien energia erradiazio-maiztasunarekiko proportzionala da. Fotoien energiak eta bi energia mailen arteko diferentziak bat egiten dutenean, materialak argia absorbatzen du eta elektroiak energia maila altuago batera salto egiten du (2a. irudia). Alderantzizko berezko prozesua ere existitzen da: elektroia egoera kitzikatutik oinarrizko egoerara itzultzen da fotoi bat igorriz; hots, berezko igorpena gertatzen da (2b. irudia). Azken prozesu hau ohiko argi-iturrien oinarria da: bonbillak, LED, eta abar.

a) Absortzioa

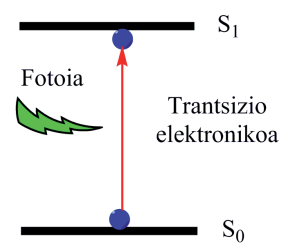

b) Berezko igorpena

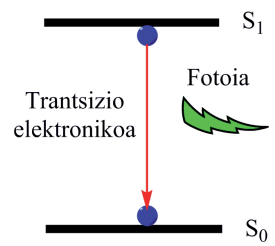

c) Suspertutako igorpena

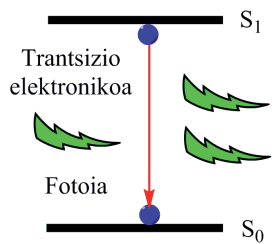

2. irudia. a) Fotoi baten absortzioa, egoera kitzikatura pasatuz. b) Atomo batek fotoi bat berez igortzen du oinarrizko egoerara itzultzen denean. c) Suspertutako igorpena: bi fotoi igortzen dira.

\subsection{Laserraren gakoa: suspertutako igorpena}

Aurreko atalean azaldu den moduan, gerta daiteke modu espontaneo batean energia maila altuago batean dagoen elektroi batek oinarrizko egoerara salto egitea prozesuan fotoi bat igorriz (berezko igorpena). Baina, zer gertatzen da egoera kitzikatuan dagoen atomo berdina eremu elektromagnetiko baten aurrean badago? Fotoi batek eta aurretik kitzikatuta dagoen atomo batek elkarri eragiten badiote, atomoa bere oinarrizko egoerara itzultzeko gai da fotoi berri bat igorriz. Beraz, suspertutako igorpenean, berezko igorpenean gertatzen ez den moduan, aurretik gutxienez fotoi bat beharrezkoa da. Horrela, trantsizioak berez sortzen duen fotoiaz gain, beste bat edukiko dugu, suspertutako igorpenak sortzen duena, hain zuzen ere (2c. irudia). Gainera, atomoak igortzen duen fotoiak hasierako fotoiaren propietate berdin-berdinak ditu. Fenomeno honek prozesu berbera behin eta berriro errepikatzea eragin dezake, baldin eta fotoi kopuruaren handipen horrek ingurunean dauden beste atomo kitzikatuen igorpenak suspertzen baditu [12]. 
Beraz, esan daiteke suspertutako igorpenari esker argiaren anplifikazioa lortzen dela; laserra oinarritzen den printzipioan, hain zuzen ere.

\subsection{Populazioaren inbertsioa}

Orokorrean, laserrak eduki dezakeen edozein ingurune aktibo (gasak, likidoak eta solidoak) oinarrizko egoeran eta egoera kitzikatuan dauden atomoez osatuta dago. Esan bezala, oinarrizko egoeran dauden atomoek argia absorbatzen dute, eta egoera kitzikatuan daudenek, berriz, suspertutako igorpenaren bitartez, argia anplifika dezakete. Bi prozesuek konstante berari jarraitzen diotenez, absortzio/anplifikazio osoaren balantzea oinarrizko egoeran eta egoera kitzikatuan dauden atomo kopuruen arteko zatiki erlatiboaren menpe dago. Beraz, anplifikazio garbi bat lortzeko, atomo kitzikatuen kopurua oinarrizko egoeran daudenena baino altuagoa izan behar da. Baldintza hori populazio-inbertsio izenaz ezagutzen da (3. irudia); ingurune aktiboan aurrera eramaten da, eta ezinbestekoa da laserraren funtzionamendurako. Populazio-inbertsioa ez da egoerarik ohikoena naturan: egoerarik egonkorrena, eta horregatik populatuena, oinarrizko egoera da. Ondorioz, inbertsioa posible izateko, beste laguntza bat beharrezkoa da, ponpaketa, hain zuzen ere.

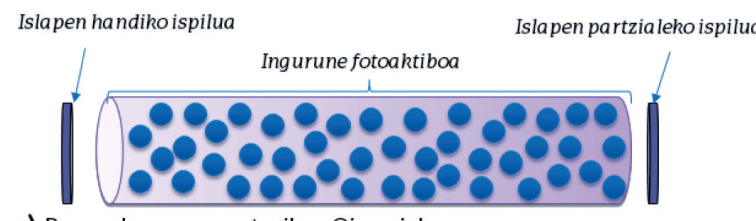

a) Barrunbe erresonatzailea. Oinarrizko egoeran

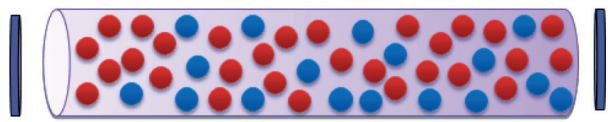

b) Populazioareninbertsioa



c) Berezko igorpenak eragiten du suspertutako argiaren igorpena
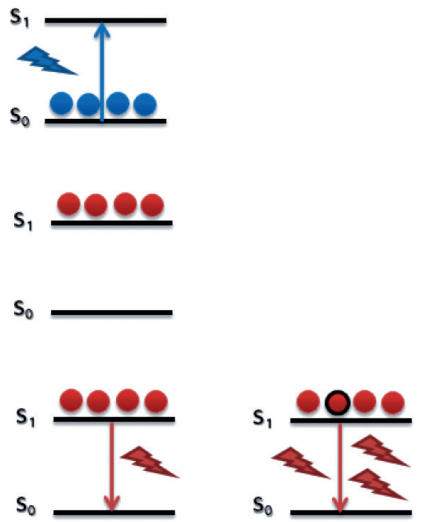

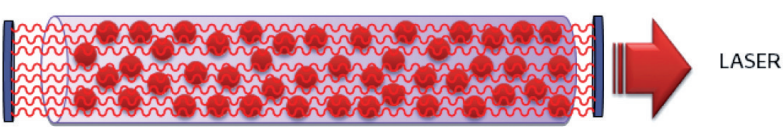

d) Argiaren anplifikazioa, koherentea eta fasean dagoena

3. irudia. Barrunbe erresonatzailearen atalak eta laser-igorpena eskuratzeko haren barnean gertatzen diren ondoz ondoko prozesuak (urdinez,oinarrizko egoeran dauden elektroiak, eta gorriz, egoera kitzikatuan daudenak). 
Koloratzaile-laserra, ezinbesteko argi iturria eguneroko bizitzan

\subsection{Ponpaketa}

Ezohiko egoera bat denez, ingurune aktiboan populazio-inbertsioa posible egiteko, kanpoko mekanismo baten beharra dago, hots, ponpaketa [13]. Ponpaketa optikoa (lanpararen deskarga baten bidez edo beste laser bat erabiliz) eta elektrikoa (korronte elektriko bizia dela medio) dira ohikoenak. Baina, materialaren atomoek erradiazioa igortzen duten heinean atomo kitzikatuen zatikia txikituz joaten denez, oinarrizko egoeran dauden atomoen kopurua handitzen da, eta denborarekin populazio-inbertsioa desagertzen da. Horrela, hasierako materialak, anplifikadore moduan lan egin beharrean, absorbatzaile moduan lan egingo luke. Ponpaketak, beraz, atomo kitzikatuen galera orekatu eta denboran zehar populazio-inbertsioa mantendu behar du, gerora, anplifikazio-prozesua ahalbidetzeko. Laserraren funtzionamendua mantentzeko, etengabea izan behar du ponpaketak. Ponpaketa era konstantean egiten bada, erradiazioaren irteera etengabea da, eta laserrak uhin jarraituan (cw, continuous wave) lan egiten duela diogu. Aldiz, ponpaketa etena bada, lehenik, populazio-inbertsioa egiten da; ondoren, goiko maila husten da, eta erradiazio pultsu bat igortzen da (pultsuzko moduan lan eginez).

\subsection{Laser-barrunbea}

Laserrean parte hartzen duten osagai nagusiak ikusi arren, ingurune aktibo baten (hots, material anplifikatzaile) eta ponpaketa-mekanismo baten arteko konbinazioa ez da nahikoa laserraren funtzionamendurako. Alde batetik, uhin-luzeraren kontrol zorrotza beharrezkoa da, eta, bestetik, eskuragarri izan behar dugu argi iturri-distiratsua (ingurunea anplifikatuz lortuko genukeena baino intentsitate altuagokoa). Bi baldintza horiek modu errazean lortzen dira: ingurune aktiboa bi ispiluz osatutako barrunbe batean kokatuz (3. irudia). Jakina, ispilu horietako bat partzialki islatzailea izan behar da; erradiazioaren zati handiena hartzen du barrunbearen barruan, baina, aldi berean, horren frakzio txiki bat kanpora irteten uzten du, laser sorta eratzeko.

Laserretan, aurrez aurre kokatutako bi ispiluz osatuta dagoen barrunbe itxi bati dagokio erresonantzia-kutxa; bertan, eremu elektromagnetikoa ispilu perfektu batean deuseztatu behar da. Hori dela eta, barrunbean, hormetan deuseztatzen diren eremu elektromagnetikoaren uhinak soilik egon daitezke, uhin-luzeraren hautaketa sistema ezarriz.

Bestalde, barrunbeak, laser-igorpenaren funtsezko eraginkortasuna ere hobetzen du. Barrunbeko ispiluek sistema berriro elikatzen dute: ingurune aktiboan anplifikatutako argia islatuz eta bertatik berriro pasatuz, argia gehiago anplifikatzen da. Horretarako, ezinbestekoa da fotoiak barrunbearen ardatzarekiko lerrokatuta egotea; bestela, azken hauek mugetan absorbatuak izango dira. Horregatik, barrunbeak fotoien norabideen hautaketan 
ere hartzen du parte, laser igorpenaren norabidea oso zehaztuta egonik. Azkenean, barrunbearen barruan energiaren irabaziek galerak gainditzen dituztenean, islapen-ispilu partzialean zehar laser igorpena eskuratzen da.

\subsection{Laser-argiaren propietateak}

Orain arte azaldu den laser-funtzionamendu bitxi honek propietate oso bereziak edukitzera behartzen du gailua. Izan ere, anplifikazioa eta suspertutako igorpenaren berezko natura (3. irudia) laser-argiaren propietateen oinarrizko arrazoiak dira. Propietate horiek koherentzia, monokromatizitate eta norabide zuzena (1. irudia) dira.

Uhin elektromagnetikoak bidean eta denboran zehar bere fasea zoriz aldatzen ez duenean, uhin hori koherentea dela esaten da. Naturan daukagun argi-iturriek fase aldakorra duten uhinak igortzen dituzte, berezko igorpenaren izaera dela eta. Hortaz, ohiko argi-iturriek koherentziarik ez edukitzea normala da. Baina laser batean suspertutako igorpenari esker igortzen diren fotoi berriek, aurretik igorritakoekin konparatuta berdin berdina denez, eremu elektromagnetikoaren faseari modu berberean eragiten diote, laserraren argia koherentea izanez. Propietate hau laserrak aurkezten dituenen artean bikainena da, hainbat aplikazioetan erabiltzen delarik.

Berriro suspertutako igorpenaren ondorioz, fotoiek, berdinak direnez, uhin-luzera bera aurkezten dute. Are gehiago, barrunbeak uhin-luzera konkretu baten erradiazioa hautatzeko aukera ematen digu. Beraz, laserrak igortzen duen argia monokromatikoa da; hots, uhin-luzera bakar batean jarduteko gai da.

Barrunbearen ondorioz, ispiluekiko perpendikularki mugitzen diren fotoiek soilik anplifikatzen dute argia. Horrela, argiak norabide zuzen bat duela esaten da [14]. Azken hau, baliagarria da leku konkretu batean energia kontzentratzea beharrezkoa denenerako.

Ikus daitekeenez, hiru propietate horiek ez dira ohiko argi-iturrietan agertzen (1. irudia). Hortaz, laserrari esker daukagun argia berezia da, hamaika aplikaziotarako premiazko bihurtu da, eta gaur egungo bizimodua goitik behera aldatu du. Halere, bilatzen dugun helburuaren arabera erabiltzen diren laserrak desberdinak dira. Hortaz, ikus ditzagun laser motak.

\section{LASER MOTAK}

Gaur egun laser desberdinen kopurua oso handia denez, zehaztasunez azaltzeko entziklopedia bat beharko genuke laser bakoitzeko. Laser motak sailkatu nahi baditugu, irizpide ezberdinak erabil daitezke: uhin-luzera, tamaina, potentzia ... Baina modurik egokiena eta baliagarriena ingurune ak- 
tiboaren arabera sailkatzea da, ingurune hori azken hau kitzikapen mekanismoarekin lotuta baitago. Horren arabera, laserrak hiru familia handitan banatu ahal ditugu: gasezkoak, likidozkoak eta solidozkoak.

Lehen motako laserrek ingurune aktibo moduan gas bat erabiltzen dute, edo gas batzuen nahasketa. Ingurune aktiboaren bolumena oso handia izan daitekeela dute abantaila, laser solidoen kasuan ez bezala. Gainera, merkeak ere badira. Horien artean gas neutrozko laserrak ditugu. Helio-Neon $(\mathrm{He}-\mathrm{Ne})$ laserrak eremu gorrian lan egiten du, 632,8 nm-an, hain zuzen ere. Baina ionizatutako gasezko laserrak $\left(\mathrm{Ar}^{+}\right)$, laser molekularrak $\left(\mathrm{CO}_{2}\right)$ eta eszimero-laserrak (1.taula) ere badaude.

1. taula. Ohiko laserrak eta haien propietate nagusien laburpena ingurune aktiboaren arabera.

\begin{tabular}{|c|c|c|c|c|c|}
\hline Mota & Laserra & $\begin{array}{c}\text { Uhin-luzera } \\
(\mathrm{nm})\end{array}$ & $\begin{array}{c}\text { Lan egiteko } \\
\text { modua }\end{array}$ & Potentzia & $\begin{array}{c}\text { Pultsuaren } \\
\text { iraupena }\end{array}$ \\
\hline \multirow{5}{*}{ Gas } & $\mathrm{He}-\mathrm{Ne}$ & 632.8 & Jarraitua & $0,5-5 \mathrm{~mW}$ & \\
\hline & $\mathrm{Ar}+$ & $488,514,5$ & Jarraitua & $1 \mathrm{~mW}-1 \mathrm{~W}$ & \\
\hline & $\mathrm{CO}_{2}$ & 9600,10600 & $\begin{array}{l}\text { Jarraitua } \\
\text { Pultsuzkoa }\end{array}$ & $\begin{array}{c}1 \mathrm{~W}-10 \mathrm{KW} \\
\mathrm{GW}\end{array}$ & $\mu \mathrm{s}-\mathrm{ns}$ \\
\hline & $\mathrm{N}_{2}$ & 337,1 & Pultsuzkoa & $250 \mathrm{KW}$ & ns \\
\hline & Exzimero $\left(\mathrm{ArF}^{*}\right)$ & 193 & Pultsuzkoa & MW & ns \\
\hline Likido & Koloratzaile & $320-1200$ & $\begin{array}{l}\text { Jarraitua } \\
\text { Pultsuzkoa }\end{array}$ & $\begin{array}{c}0,1-3 \mathrm{~W} \\
50 \mathrm{~mJ}-1 \mathrm{~J} / \text { pultsuko }\end{array}$ & $\mu \mathrm{s}-\mathrm{ns}$ \\
\hline \multirow{4}{*}{ Solido } & Errubi & 694,3 & Pultsuzkoa & $100 \mathrm{~J} /$ pultsuko & $\mu \mathrm{s}-\mathrm{ns}$ \\
\hline & Nd-YAG & 1064,1 & $\begin{array}{l}\text { Jarraitua } \\
\text { Pultsuzkoa }\end{array}$ & $\begin{array}{c}1 \mathrm{~W}-100 \mathrm{KW} \\
1 \mathrm{~J} / \text { pultsuko }\end{array}$ & ns \\
\hline & Ti-zafiro & $660-1180$ & $\begin{array}{l}\text { Jarraitua } \\
\text { Pultsuzkoa }\end{array}$ & $\begin{array}{c}2,5 \mathrm{~W} \\
\mathrm{TW}\end{array}$ & ps-fs \\
\hline & Diodo & IR-urdina & Jarraitua & $10-1.000 \mathrm{~mW}$ & \\
\hline
\end{tabular}

Egoera solidozko laserretan, ingurune aktibo bezala erdieroaleak erabil daitezke (adibidez GaAs edo AlGaAs). Bi erdieroale lotzen direnean ( $\mathrm{p}$ motako erdieroale bat $\mathrm{n}$ motako batekin) diodo esaten zaie (1. taula) eta erdieroale guztietan dagoen salto energetikoak (gap zabalera) lan egiteko uhin-luzera zehazten du. Ingurune aktiboan, ioi proportzio txiki batekin ( \% 1) dopatuta dauden solidoak ere erabiltzen dira (kristala edo beira). Ioi moduan, batez ere trantsizio metalak $(\mathrm{Cr}, \mathrm{Ti}$...) edo lur arraroak 
$(\mathrm{Nd}, \mathrm{Er}, \mathrm{Yb} \ldots)$ erabiltzen dira, eta oinarri moduan, edo matrizea, kristal gogorra, beiraren bat edota material zeramiko bat. Egoera solidozko lehenengo laserra errubizkoa izan zen. Halere, gaur egun Nd-YAG laserra da erabiliena (1. taula). Talde horretan, eremu gorrian edo infragorrian lan egitea da ohikoena; halere, ultramorean lan egiten duten diodo-laser komertzialak gero eta gehiago ekoizten ari dira.

Egoera likidozko laserretan, koloratzaile fluoreszenteak (normalean kromoforo organikoak) uretan edo disolbatzaile organikoetan disolbatzen dira. Laser horiei koloratzaile-laserrak edo laser organikoak deitzen zaie. Horien ezaugarri berezi eta moldagarriak direla eta, arreta suspertu dute gure ikerketa-taldean. Hurrengo atalean, laser mota hau gehiago aztertuko da eta orokorrean egindako aurrerapausoak aipatuko dira.

\subsection{Koloratzaile-laserrak}

Orain arte azaldu ditugun laser horiek guztiek uhin-luzera konkretu batean lan egiteko aukera aurkezten dute. Nahiz eta zuzentasun eta monokromatizitate horiek oso perfektuak izan, sintonizagarritasun ezak aplikazioak mugatzen ditu. Izan ere, aplikazio bakoitzerako laser bat esleituta dago, eta laser hori ezin da erabili aplikazio desberdinetan; hau da, ezin da laser bakarra erabili aplikazio kopuru baterako. Egia da optika ez-lineala erabiliz aurreko laserren igorpenaren harmonikoak $(\lambda / 2, \lambda / 3)$ lortu ahal direla. Adibidez, Nd:YAG laserraren ohiko igorpena $1064 \mathrm{~nm}$-an dago, baina bere laser-seinalea $532 \mathrm{~nm}$ eta $355 \mathrm{~nm}$-an ere lor daiteke. Hala eta guztiz ere, sintonizatze hori ez da nahikoa aplikazio guztien eskakizunak betetzeko. Hori lortzeko, uhin-luzera tarte batean lan egiteko gai den laser bat beharrezkoa da eta azken hau fluoreszenteak diren koloratzaile organikoekin lor daiteke. Horretarako, fotofisikaren ikuspuntutik, molekula organikoek baldintza batzuk bete behar dituzte laser-koloratzailetzat hartzeko, laser-igorpena lortzeko dentsitate optiko altuak behar baitira: (i) absortzio- eta igorpen-banda sendoak izatea, ponpaketaren erradiazioa eraginkortasunez xurgatzeko eta suspertutako igorpenaren anplifikazioa errazteko; (ii) egonkortasun kimikoa, termoegonkortasun (barrunbean sortzen den tenperaturagatik gradientearekiko erresistentzia) eta fotoegonkortasun (ingurune aktiboa hondatu gabe jasan ahal diren ponpaketen pultsu jarraituak) altuak izatea onuragarria da, ingurune aktiboa iraunkorra izan dadin.

Sistema organiko horiek uhin-luzera tarte batean lan egitea ahalbidetzen dute; hots, laser-banda zabalak aurkezten dituztenez (4. irudia), uhinluzera batetik bestera mugitzeko aukera dago, eta, horrela, aplikazio desberdinetarako lan egin daiteke. Horregatik, laser sintonizagarrien ingurune aktibo modura jokatzen dute. Ezaugarri honek pultsu oso laburrak (ikusi 2.4 atala) eskuratzea ere ahalbidetzen du, ezinbestekoa dena prozesu kimikoak aztertzeko euren dinamika oso azkarra baita. Gainera, eta kimika 
organikoan egindako aurrerapausoei esker, gaur egun ultramoretik (UV) infragorrirako (IR) ikusgaia (Vis) zeharkatuz doan eremua osatzen duten koloratzaile-laser familia desberdinak garatu dira (4. irudia). Hori dela eta, gaur egun koloratzaile fluoreszente berrien garapena sustatu da, bai molekulen egitura aldatuz bai koloratzaile familia berriak diseinatuz. Laser-koloratzaile komertzialen familia desberdinen artean, honako hauek azpimarratu behar dira (8. irudia): kumarinak (UV eta ikusgaiko alde urdinean), xantenoaren deribatuak (errodaminak edo fluoreszeina, Vis-ko eremu berde-gorria osatuz) eta oxazinak (nilo urdina edo bioleta kresiloa) edo estiriloan oinarritutakoak (azken biak, ikusgaiko ertz gorrian eta IR-ko hurbilean).

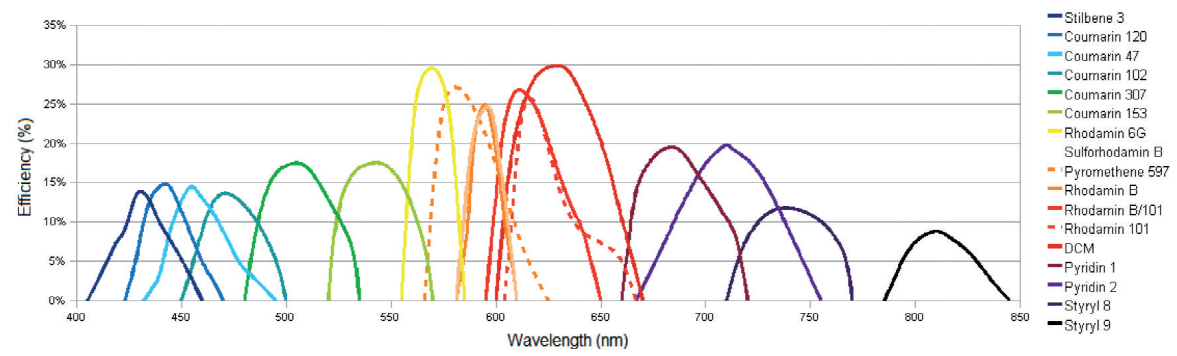

4. irudia. Zenbait laser-koloratzaileren bandak eremu ikusgaian zehar [15].

Gorago adierazi den bezala, gure ikerketa-taldean era honetako koloratzaile-laserrei eman diegu (laser organikoak ere deitzen direnak [16, 17]) arreta handia. Azken urteotan gure helburu nagusietako bat koloratzaile eta material berri hobeak (eraginkortasunaren eta egonkortasunaren aldetik) garatzea izan da, laser organiko sintonizagarrietan ingurune aktibo moduan erabil daitezen. Hau da, denboran zehar laser seinalea are eta ahaltsuagoa eta iraunkorrago izatea, hurrenez hurren, nahiz eta irradiazio intsentsuak etengabe jasan. Horretarako, zenbait estrategiari jarraitu zaie. Aztertutako jokabideak jarraian laburbiltzen dira.

\subsubsection{BODIPYan oinarritutako koloratzaile-laserrak ikusgai eremu osoan zehar}

Gaur egun eskura dauden fluoroforoen artean, boro-dipirrometeno (BODIPY) izenekoek izan duten arrakasta itzela [18]. Eremu berde-horian ezaugarri fotofisiko ezin hobeak erakusteaz gain, haien abantaila nagusia dipirrina nukleoaren moldagarritasun sintetikoan datza. Hori dela eta, kromoforoa ordezkatzaile ugariekin sakonki funtzionaliza daiteke. Era berean, ezarritako ordezkapenak guztiz aldatzen ditu koloratzailearen ezaugarri espektroskopikoak. Honetaz baliatuz, BODIPYaren oinarrizko egitura eral- 
datu da ikusgaiko bi ertzetara (hau da, alde urdinera zein gorrira) absortzioeta igorpen-bandak kontrolpean lerrokatzeko. Ondorioz, BODIPY urdinak garatzeko, meso posizioan, elektronegatibitate ezberdineko heteroatomoak txertatu dira, eta BODIPY gorriak lortzeko, ordea, $\pi$ sistema hedatu da talde aromatikoak txertatuz (arilok fusionatuz edo interakzio erresonatzaileak areagotuz eraztun aromatikoak lotuz) (5. irudia). Lortutako laserseinaleak ia eremu ikusgai osoa betetzen du (5. irudia), eta haren jarrerak gainditu egiten ditu, seinalearen eraginkortasun aldetik eta batez ere fotoegonkortasun aldetik, eremu bakoitzean orain arte optimotzat jotzen ziren koloratzaile-laserrak (adibidez, kumarinak urdinean; errodaminak laranjan, eta oxazinak edo estiriloak gorrian). Esate baterako, eremu urdinean laser-eraginkortasuna (lortzen den energiaren eta sartzen denaren arteko erlazio) \% 30-\% 50 da eta, 40.000 pultsu ostean, seinalearen \% 40-\% 70 mantentzen da; eremu berde-horian eraginkortasuna \% 70ra igotzen da, eta baldintza berdinetan seinalearen $\% 90$ mantentzen da eta eremu gorrian $\%$ 45-\% 60ko eraginkortasunak lortzen dira seinalea ia hondatu gabe (fotoegonkortasuna \% 100). Izan ere, BODIPYek erradiazio ahaltsuak (ponpaketan gertatzen den bezala) eta luzeak jasan ahal dituzte ia hondatu gabe. Horrenbestez, laser-seinaleak, espektro-tarte zehatz batean bizia eta sintonizagarria izateaz gain, seinaleak luzaro irauten du, eta laserraren bizitza nabarmenki luzatzen da.

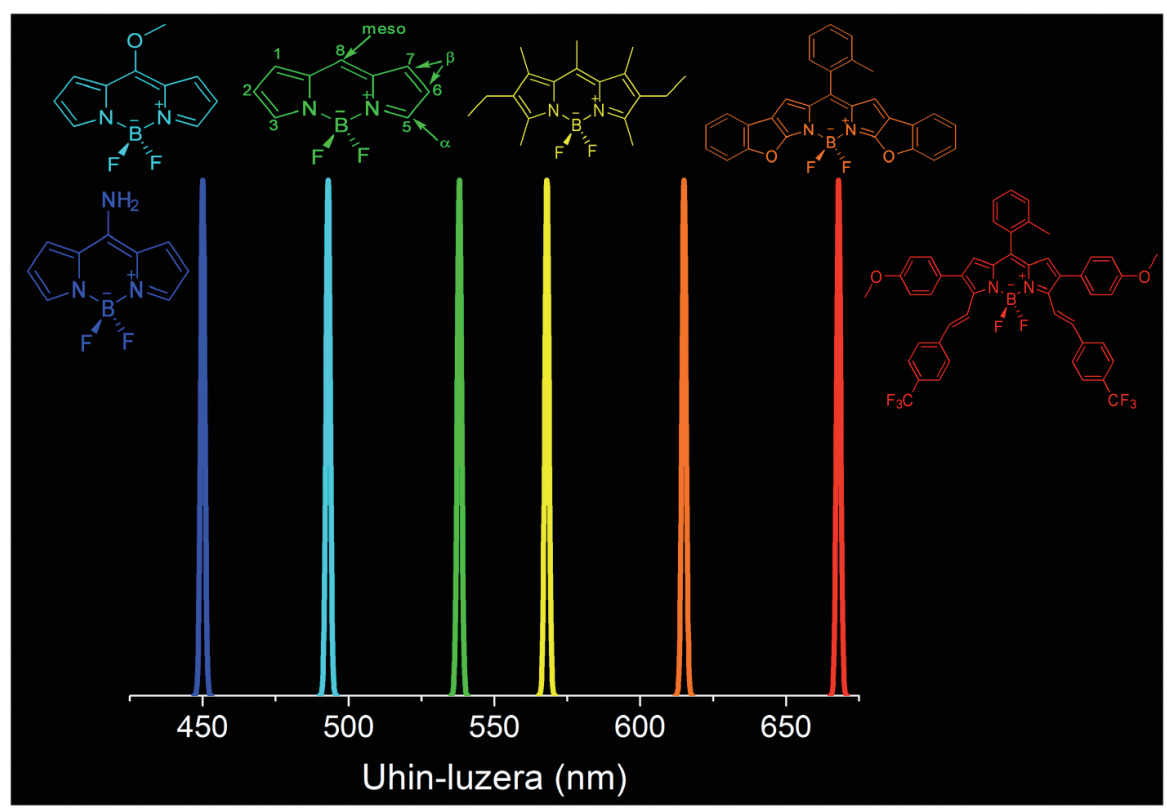

5. irudia. Zenbait BODIPY koloratzaileren laser-igorpena eremu ikusgaian zehar. 
Koloratzaile-laserra, ezinbesteko argi iturria eguneroko bizitzan

\subsubsection{Koloratzaile multikromoforikoak energia-truke bidezko laserretarako}

Kimika organikoaren baliabideaz profitatuz, koloratzaile desberdinak kobalenteki lotu ahal dira egitura multikromoforikoa eratzeko. Horretarako, arrazoinatuz kromoforoak eta haien arteko lotura aukeratu behar dira. Alde batetik, lotura kobalentea eratu eta gero, kromoforo bakoitzak bere izaera molekularra mantendu behar du. Interakzio erresonatzailerik gertatuz gero, entitate kromoforiko berri bat sortzen da. Beraz, koloratzaile multikromoforikoetan azpiunitateen arteko isolamendu elektronikoa bilatzen da. Modu honetan, unitate bakoitzak fluoroforo berriaren propietateetan eransgarri gisa parte hartzea lortzen da. Beste alde batetik, koloratzaile bakoitzak espektro-gune desberdinetan argia xurgatu eta igorri behar du. Modu honetan, koloratzaile multikromoforikoaren xurgapena espektro-tarte zabal batean izatea bermatzen da. Are gehiago, energia-trukea (Excitation Energy Transfer, EET) ahalbidetzen bada lotuta dauden kromoforoen artean, nahiz eta ikusgaiko edozein eremu espektraletan xurgatu, igorpen gorria lortzen da esklusiboki. Honetarako, emailearen fluoreszentzia-bandaren eta hartzailearen absortzio-bandaren arteko espektrogainezarpena beharrezkoa da.

Eskakizun hauek guztiak kontuan hartuz, absortzio zabaleko koloratzaile multikromoforikoak garatu ditugu, aurreko puntuko BODIPY koloratzaile aproposak erabiliz [19], edo komertzialki eskura dauden koloratzaileak konbinatuz (adibidez, kumarina-BODIPY-perileno) [20]. Lotura kobalenteagatik energia-emailearen eta hartzailearen arteko distantzia oso txikia denez, energia-truke intramolekularra oso eraginkorra da (ia \%100). Ondorioz, sistema multikromoforiko hauek antena molekulartzat hartu ahal dira. Hau da, absortzio-bandak eremu ikusgai osoan zehar hedatzen dira, eta, edozein uhin-luzeratan kitzikatu ostean, hartzailearen igorpen gorria berreskuratzen da beti (6. irudia). Laserretarako honako sistemak oso interesgarriak dira, ponpaketa asko errazten baita, izan ere populazio inbertsioa sorrarazteko laser desberdinak erabil daitezke, absortzio-banda desberdinak daudelako. Gainera fotoegonkortasuna nabarmenki handitzen da, laser-seinalea igortzen duen kromoforoak ez baita zertan zuzenean kitzikatu behar. Energia trukatzeko prozesuari esker, energia-emaile den edozein unitatea kitzikatu ahal da igorlea den kromoforoa hondatu gabe. Hurbilketa hau oso egokia da laser gorriak garatzeko. Laser horiek bioteknologian erabil daitezke, erradiazio mota horrek gorputzean sakontasun handiagoa aurkezten du eta. Baina eremu honetan lan egiten duten koloratzaileek orokorrean fotoegonkortasun baxua erakusten dute. Sistema multikromoforikoak erabiliz konpontzen da oztopo hori. Esate baterako, 10. irudiko koloratzaile multikromoforikoa erabiliz, $630 \mathrm{~nm}$-an eta $665 \mathrm{~nm}$-an lortzen da laser-seinalea. Seinalearen eraginkortasuna \% 35 eta \% 50ekoa da, eta bi kasutan fotoegonkortasuna \% 100ekoa da 100.000 pultsu ostean. 

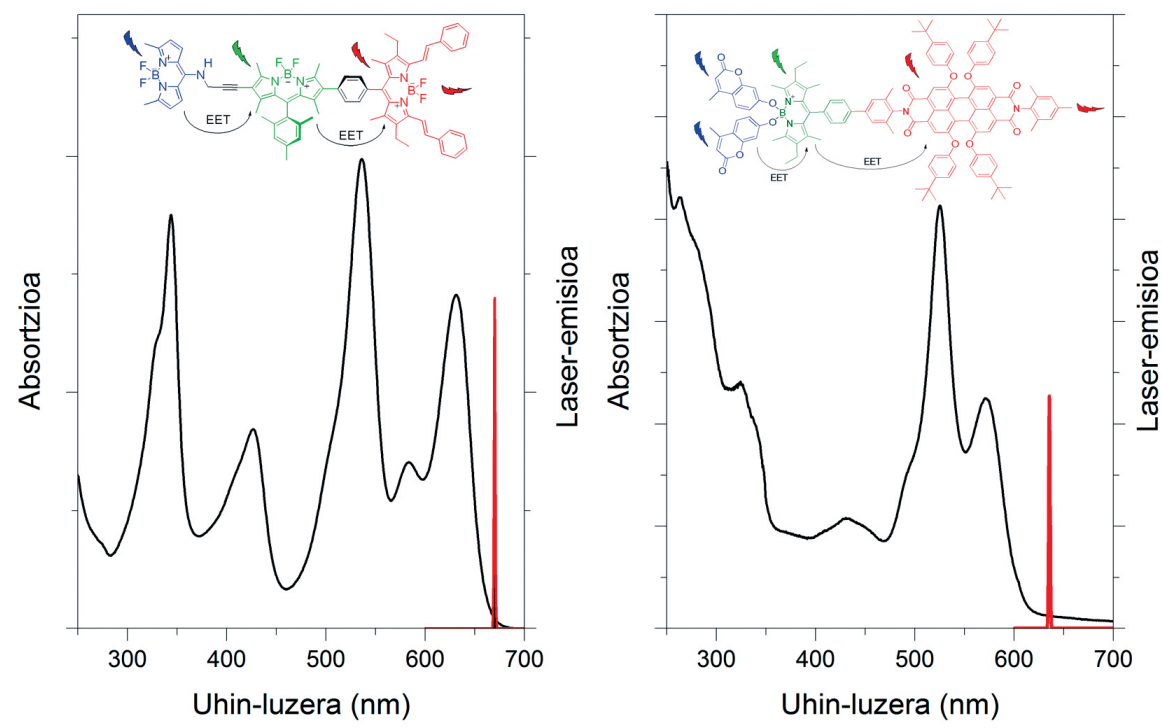

6. irudia. Koloratzaile multikromoforikoen absortzio- eta laser-espektroak (ponpaketa $355 \mathrm{~nm}$-an). Molekulen egitura ere erakusten da energia-trukea (EET) aipatzeko.

\subsubsection{Koloratzailez dopaturiko latex-nanopartikuletan oinarritutako atzeraelikadura-laserrak}

Gorago aipatutako energia-trukea era intermolekularrean ere gerta daiteke energia-emailea eta hartzailea lotuta egon barik. Baina, energia-trukearen probabilitatea distantziaren menpe dagoenez, kontzentrazio altuak behar dira. Energia-trukea areagotzeko konponbide egokia energia-emaile eta hartzailea nanopartikuletan (NP) konfinatzea da [21]. Modu honetan, hurbilago egotera behartzen dira bi emaileak. Hori dela eta, errodamina 6G (emaile moduan) eta nilo urdina (hartzaile moduan) tamaina txikiko (40-70 nm) latex-nanopartikula esferikoetan konfinatu dira (7. irudia). Dopaturiko NP horiek ondo suspenditzen dira uretan koloide egonkorrak sortuz. Ingurune honetan, energia trukea bideragarria da. Aurreko puntuarekin lotuta, egonkortasuna oso ona da, ez baita beharrezkoa nilo urdina zuzenean ponpatzea: errodamina kitzika daiteke (koloratzaile honek oso ondo jasaten du ponpaketa), eta energia-trukearen bidez, nilo urdinaren igorpen gorria lortzen da. Oxazina hori ez da batere egonkorra, eta berehala hondatzen da disoluzioan, baina NPetan barneratuz eta energia trukea sorraraziz, bere fotoegonkortasuna nabarmenki igotzen da. Are gehiago, energiatrukearen eraginkortasuna emaile-hartzaile erlazioaren bidez ondo modula daiteke. Beraz, errodaminaz dopaturiko NPetan laser horia behatzen da. NPetan nilo urdina apur bat sartuz, laser-gorpen bikoitza lortzen da, energia trukea partziala delako. Koloratzaile horren kantitatea handituz, laser 
gorria lortzen da esklusiboki, nahiz eta errodamina kitzikatu, energia trukea erabatekoa delako. Ondorioz, laser-igorpena $700 \mathrm{~nm}$-an lor daiteke; bere eraginkortasuna $\% 20$ da, eta 50.000 pultsu ostean, seinalearen $\% 90$ mantentzen da (7. irudia).

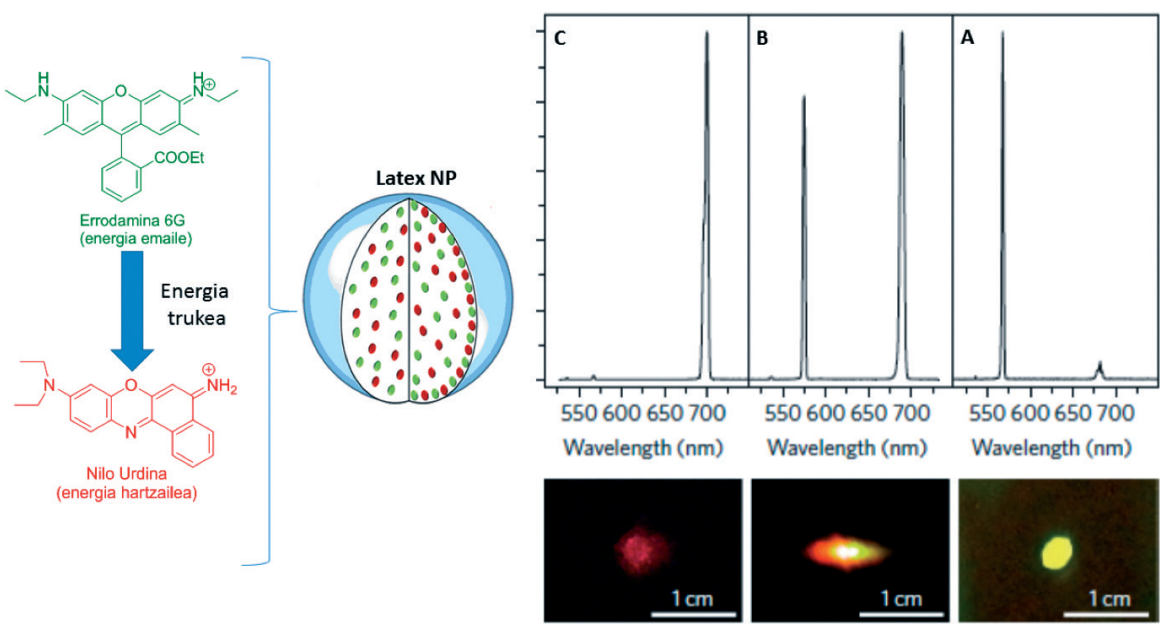

7. irudia. Energia-trukea areagotzeko latex-nanopartikuletan konfinatutako koloratzaileak. Laser-igorpena errodaminaz dopaturiko NPetan (A), nilo urdinarekin batera (B) eta azken koloratzaile horren kantitatea handituz (C).

Honetaz gain, latex-nanopartikula txiki horiek, sortutako argiaren dispertsioagatik, anplifikazio prozesua indartzen dute barrunbe erresonatzailean (ikusi 2.6 atala). Normalean, dispertsio hau oso handia denean (adibidez, NP handiak erabiliz, tamaina $>100 \mathrm{~nm}$ ) galerak handitzen dira, barrunbean argia galtzen delako. Baina kasu honetan, NP tamaina txikia denez eta ondorioz eragindako argiaren dispertsio altua ez denez, prozesu hori mesedegarria da: argiak lagina aldi gehiagotan zeharkatzen du, igorpen estimulatua areagotzen da, eta, honekin batera, seinalearen anplifikazioa. Nanopartikuletan gertatzen den atzeraelikadura-prozesu honen bidez lortutako laser-eraginkortasuna koloratzaileek disoluzioan erakusten dutena baino hobea da.

\subsubsection{Laser organikoak egoera solidoan}

Normalean koloratzaile laserrak egoera likidoan erabiltzen dira, hau da, ingurune aktiboa lortzeko disoluzioak prestatzen dira molekula organikoa disolbatuz ingurune likidoan. Disolbatzaileen erabilerak eta honen fluxua ezartzeak arazoak sortzen ditu, tresneria korapilatzen delako eta gastatutako bolumenak oso handiak direlako: laser hauen mantentze-lanak garestia da. Gainera, disolbatzaile organikoak kaltegarriak eta kutsakorrak dira. 
Beraz, koloratzaile-laserren erabilera errazteko teknologian, ingurune aktiboak egoera solidoan eskatzen dira. Horretarako, koloratzaileak matrize solidoetan sartzen dira. Euren izaera organikoa kontuan hartuz, eta bateragarritasun-arazoak ekiditeko, polimeroak erabili ohi dira, nahiz eta euskarri ez-organikoak ere erabil daitezkeen (hala nola sol-gel materialak) [22]. Eskakizun hauei aurre egiteko, guk laserrak egoera solidoan garatu ditugu, 3.1 puntuko BODIPYak polimeroetan sartuz. Laserraren ezaugarriak hobetzeko aukera desberdinak frogatu ditugu [23]. Adibidez, inongo aldaketarik gabeko BODIPYak polimetilmetakrilatoan (PMMA) zuzenean sartu dira. Ingurunearen zurruntasuna areagotzeko, kopolimeroak ere erabili dira; horietan, metil metakrilato (MMA) egoteaz gain, polimerizazio-prozesuan gurutzatutako monomeroak (hala nola trimetilolpropano trimetakrilatoa, TMPTMA, edo pentaeritritol tetrakrilatoa, PETRA) ere badaude (8. irudia).

Modu honetan, koloratzailearen inguruan dagoen bolumen askea murrizten da. Ingurune solidoak koloratzailea babesten du eta galera ez-erradiatzaileak murrizten dira. Ondorioz, egoera solidoan, laser-seinale distiratsuak lortu dira (\% 25-\% 40 inguru) eta luzaro irauten dute (\% 70 mantentzen da 50.000 pultsu ostean). Fotoegonkortasuna areagotzeko, BODIPY kromoforoan monomero bera (metakrilatoa, MMA) txertatu da kobalenteki (8. irudia). Beraz, polimerizazio-prozesuan BODIPY bera monomeroaren egituraren zati bat da kate polimerikora lotuta geratuz. Estrategia honek egonkortasun termikoa handitzen du. Izan ere, soberan sortzen den gehiegizko energia kate horren bidez barreia daiteke ponpaketaren bitartean, \% 100 fotoegonkortasuna emanez aurreko ponpaketa jasan eta gero. Ondorioz, material polimeriko organiko hauek egokiak dira laser solido sintonizagarrietan ingurune aktibo moduan jokatzeko.

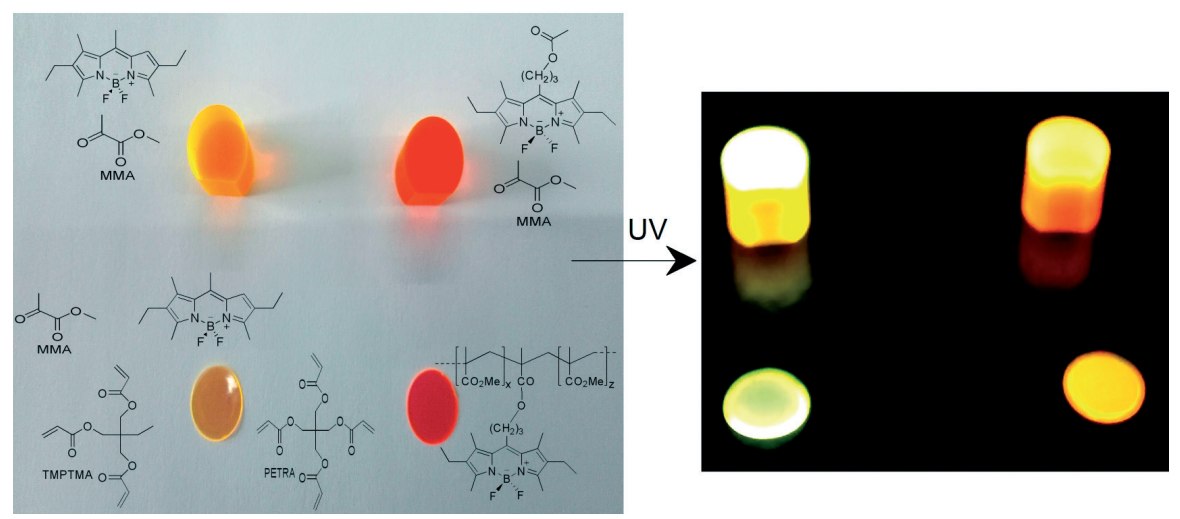

8. irudia. Lagin polimerikoak (homopolimeroak eta kopolimeroak) egoera solidoan, non BODIPYa era desberdinetan (polimeroan barreiatuta edo katearekin kobalenteki lotuta) barneratu den. Lanpara ultramorearen azpian (UV) lortzen den fluoreszentziaren igorpena ere erakusten da. 
Koloratzaile-laserra, ezinbesteko argi iturria eguneroko bizitzan

\section{ONDORIOAK}

Ukaezina da laserrak eguneroko bizitzan eta teknologian duen eragina; hainbat gailu eta teknika aurreratu oinarritzen dira eta anplifikatutako eta suspertutako igorpen mota honetan. Laserren artean, ingurune aktiboan koloratzaile organikoak daramatzatenak arreta handia jasotzen ari dira, igorpena tarte zehatz batean sintoniza daitekeelako eta, molekula-egitura aldatuz, ultramore ikusgai osoan zehar laser-igorpena lortu ahal delako. Ildo honetatik, guk, koloratzaile-laserren jokabidea hobetzeko, egitasmo desberdinak garatu ditugu. Horretarako, ikuspuntu sintetikotik molekula-egiturak moldatu ditugu. Simulazio teorikoen laguntzaz, koloratzaile multikromoforikoak diseinatu ditugu; hauetako fluoroforo batzuk nanopartikuletan kapsulatu dira, eta egoera solidoko laserrak lortzekotan, koloratzaileak polimeroetan ere barneratu dira. Lortutako laser seinalea oso ona izan da eraginkortasun zein fotoegonkortasun aldetik. Ondorioz, laser organikoetan espektro-gune desberdinetan zehar igorpen sintonizagarria lortzeko, ingurune aktibo aproposak eskuratu ditugu; orain arte existitzen ziren laserren propietateak hobetu ditugu, eta laserrari, gure garaiko argi bereziari, kontribuzio ezin hobea egin diogu.

\section{ESKER ONAK}

Artikulu hau Eusko Jaurlaritzak emandako diru-laguntzari (IT912-16 proiektua) eta doktoretza-bekari (E. A. Z.) esker gauzatu da.

\section{BIBLIOGRAFIA}

[1] REQUENA, A., ZUÑIGA, J. 2004. Espectroscopía. Pearson, Madrid.

[2] Nobel Sarien weborrialdea: https://www.nobelprize.org 2017-02-13.

[3] HECHT, J. 2005. Beam. The Race to Make the Laser. Oxford University Press, New York.

[4] HELL, S.W. 2015. «Nanoscopy with Focused Light». Angewandte Chemie International Edition, 54, 8054-8066.

[5] BETZIG, E. 2015. «Single Molecules, Cells, and Super-Resolution Optics». Angewandte Chemie International Edition, 54, 8034-8053.

[6] MOERNER, W. E. 2015. «Single-Molecule Spectroscopy, Imaging, and Photocontrol: Foundations for Super-Resolution Microscopy». Angewandte Chemie International Edition, 54, 8067-8093.

[7] BOULON, G. 2012. «Fifty years of advances in solid-state laser materials». Optical Materials, 34, 499-512.

[8] YOUSSEF, S.M. eta SALEM, R.M. 2007. «Automated barcode recognition for smart identification and inspection automation». Expert Systems with Applications, 33, 968-977. 
[9] GUDOTTI, R., MERIGO, E., FORNAINI, C., ROCCA, J.P., MEDIONI, E. eta VESCOVI, P. 2014. «Er:YAG 2,940-nm laser fiber in edodontic treatment: a help in removing smear layer». Lasers in Medical Science, 29, 69-75.

[10] STORCHI, I.F., PARKER, S., BOVIS, F., BENEDICENTI, S. eta AMAROLI, A. 2018. « Outpatient erbium:YAG $(2940 \mathrm{~nm})$ laser treatment for snoring: a prospective study on 40 patients». Lasers in Medical Science, 33, 399-406.

[11] CSLE, M. 2004. Fundamentals of Light Sources and Lasers. John Wiley \& Sons, New Jersey.

[12] HECHT, J. eta TERESI, D. 1998. Laser: light of million uses. Dover Publications, New York.

[13] FINDSEN, E. W. eta ONDRIAS, M. R. 1986. «Laser: a Valuable Tool for Chemists». Journal of Chemical Education, 63, 479-484.

[14] SCHAWLOW, A. L. 1968. «Laser Light». Scientific American, 219, 120-139.

[15] Radiant Dyes webgunea: http://www.radiant-dyes.com/index.php/products/ laser-dyes 2018-18-03.

[16] CHENAIS, S. eta FORGET, S. 2012. «Recent advances in solid state organic lasers». Polymer International, 61, 390-406.

[17] KUEHNE, A. J. C., GATHER, M. C. 2016. «Organic lasers: recent developments on materials, device geometries and fabrication techniques». Chemical Reviews, 116, 12823-12864.

[18] BAÑUELOS, J. 2016. «BODIPY dye, the most versatile fluorophore ever?». Chemical Record, 16, 355-348.

[19] DURAN-SAMPEDRO, G., AGARRABEITIA, A. R., GARCIA-MORENO, I., GARTZIA-RIVERO, L., DE LA MOYA, S., BAÑUELOS, J., LOPEZARBELOA, I. eta ORTIZ, M.J. 2015. «An asymmetric BODIPY triad with panchromatic absorption for high-performance red-edge laser emission». Chemical Communication, 51, 11382-11385.

[20] AVELLANAL-ZABALlA, E., DURAN-SAMPEDRO, G., PRIETOCASTAÑEDA, A., AGARRABEITIA, A. R., GARCIA-MORENO, I., LOPEZ-ARBELOA, I., BAÑUELOS, J. eta ORTIZ, M. J. 2017. «Rational molecular design enhancing the photonic performance of red-emitting perylene bisimide dyes». Physical Chemistry Chemical Physics, 19, 1321013218.

[21] CERDAN, L., ENCISO, E., MARTIN, V., BAÑUELOS, J., LOPEZ-ARBELOA, I., COSTELA, A. eta GARCIA-MORENO, I. 2012. «FRET-assisted laser emission in colloidal suspensions of dye-doped latex nanoparticles». Nature Photonics, 6, 621-626.

[22] COSTELA, A., GARCIA-MORENO, I. eta SASTRE, R. 2003. «Polymeric solid-state dye lasers: recent developments». Physical Chemistry Chemical Physics, 5, 4745-4763.

[23] LOPEZ-ARBELOA, F., BAÑUELOS, J., MARTINEZ, V., ARBELOA, T. eta LOPEZ-ARBELOA, I. 2008. «A general overview on the photophysics of BODIPY dyes in liquid solutions and solid polymer matrices». Trends in Physical Chemistry, 13, 101-122. 